\title{
Characteristics and Prognostic Factors of Elderly Patients in Intensive Care Unit

\begin{abstract}
Ivanilda Lacerda Pedrosa1, Maria do Carmo Andrade Duarte de Farias ${ }^{2}$ Francisco Alírio da Silva², Vanessa Rolim Barreto Cavalcante², Cláudia Sarmento Gadelha², Rodolfo Herberto Schneider ${ }^{3}$
\end{abstract}

\section{Abstract}

Introduction: The elderly often have high prevalence of chronic diseases and less organic reserves and, to determine increased demand for intensive care unit (ICU) beds, easily evolve to a critical state, resulting in a greater cost when admitted to these units.

Objective: Describing the characteristics and prognostic factors of elderly in the ICU of a public hospital in the city of João Pessoa-PB.

Methods: A cohort study with retrospective collection involving elderly aged $\geq 60$ years old, and used SPSS software, Pearson's chisquare and the Wilcoxon-Mann-Whitney tests.

Results: There were evaluated 72 elderly with an average age of 73.39 years old and average length of stay in the unit of 8.65 days. The overall mortality of the elderly was of $40.3 \%$. From the elderly admitted to postoperative most showed discharge for improvement. The postoperative period was the first cause of hospitalization and acute respiratory failure the second, being the major responsible for unfavorable outcomes in individuals investigated.

Conclusion: The reason for admission and the existence of chronic diseases may be associated with higher mortality in elderly hospitalized in intensive care unit. Thus, a better understanding of the factors related to prognosis of critically ill elderly can direct care strategies for this clientele in this hospital sector.

1 Teacher of Federal University of Paraiba UFPB. João Pessoa, Paraíba, Brazil.

2 Academic Unit of Life Sciences, Teacher's Training Center, Federal University of Campina Grande. Cajazeiras, Paraíba, Brazil.

3 Teacher of Institute of Geriatrics and Gerontology - IGG/PUCRS, Brazil.

Contact information:

Ivanilda Lacerda Pedrosa.

झ ivanildalp@hotmail.com 


\section{Introduction}

The average life expectancy of Brazilians has increased in recent years. In 1960 it was of 54.6 years old, in 2003 rose to 71.3 years old, and in 2010 reached 73.4 years old. [1] This increase that has occurred in recent years seems to reflect in an increased demand of older people for health services, resulting in significant increase in hospital admissions and consequently an increase in intake of the elderly in intensive care units (ICUs). [2]

These hospitals units are the sectors most affected by this phenomenon, since patients over 65 take up a considerable number of beds, consequent to complaints that affect this age group, requiring intensive care. [2-4]

This population group usually with high prevalence of chronic diseases and less organic reserves and to determine increased demand for ICU beds, easily evolve to a critical state, resulting in a greater cost when admitted to these units.

It is notable that as a person ages, many physiological processes change up and these age-related changes, put the critically ill elderly at increased risk for complications. [5] Chronic diseases and exacerbations of these, the use of several drugs the geriatric syndromes and the decline in immune function, are factors that, individually or in combination, predispose the elderly to a serious situation, which requires a multidisciplinary approach in intensive care. [6] In addition, exacerbations of chronic diseases, cardiovascular and respiratory disorders more often justify the referral of patients to the ICU. [2]

The team working at these units develops complex activities that require handling equipment with high technology, specific knowledge and skills for the care and treatment of their clientele. In assisting the elderly, the team must also understand the peculiarities inherent to this audience, paying attention to the relationship between chronic diseases and the factors that generate decompensation, and the role of these units to correct such situations. [7]
It is known that the intensive care staff are still reluctant to admit elderly patients in the ICU, especially above $80,[8]$ the reduced number of beds, not corresponding to the increase in demand that occurs due to population aging, currently exists; the high cost given the high complexity and mainly in cases of underlying diseases or end-stage dementia at an advanced stage. In Brazil, the elderly account for $42 \%$ to $52 \%$ of admissions to the ICU and consume about $60 \%$ of the available daily. $[2,9]$

So, the discussion about the elderly in ICU admission and the maintenance of their hospitalization in this unit is general in literature, becoming of fundamental importance to study the clinical characteristics of elderly ICU and factors related to the prognosis of this clientele during their hospitalization.

This study aimed to describe the characteristics and prognostic factors of elderly in the intensive care unit of a public hospital in the city of João Pessoa-PB, Brazil.

\section{Method}

This is a cohort study involving elderly in ICU, with retrospective data collection, performed in the ICU of the Hospital University Lauro Wanderley (UHLW), of the Federal University of Paraiba, with 07 beds, located in the city of João Pessoa - PB, Brazil.

Data collection was conducted in June and July 2011, from the information contained in the medical records filed in the medical and statistical file service, and filled out a form built with the goal of raising the variables: age, sex, marital status, origin, date of admission and discharge from the ICU, outcome, reason for hospitalization, main diagnosis upon admission to the ICU and chronic diseases associated with hospitalization.

For the implementation of the research there were considered in all phases of the study, the ethical aspects governing research on human beings, 
according to the terms of Resolution $466 / 12$ of the National Health Council of the Ministry of Health (CNS/MS), Brazil. [10] the research project was approved by the Ethics Committee for research hospital where the study was conducted.

Data were processed and analyzed using the Statistical Package for Social Sciences (SPSS), version 17.0. The description of the variables was performed by the frequency as well as average and standard deviation (SD). To compare the frequency of the variables among the elderly who were discharged and those who died, and between the clinical characteristics and the age of the elderly, we used the Pearson's chi-square and Wilcoxon-Mann-test Whitney for interval variables. The significance level for statistical tests was of $5 \%(p<0.05)$.

\section{Results}

In the present study it was observed that between the months of January to December 2010 period of time to investigate the profile of the elderly, were hospitalized 349 patients in the unit of study, identified only 265 records, among these, 72 (27.2\%) were elderly. There were excluded 84 records because of incomplete data or not their location.

Among the elderly, 28 were women and 44 men, aged 60-96 years old, and average of 73.39 years old $( \pm 8.85)$. The residence time ranged from 1-62 days of hospitalization, with an average of 8.65 days ( \pm 12.64$)$. The overall mortality of the elderly in ICU was of $40.3 \%$.

Table 1 shows the distributions of variables described: age, gender, marital status and origin. As can be seen, the hospitalization rate in the age group of 60-69 (37.5\%) years old was highest, followed by the elderly between 70-79 years old. Most of the sample was male (61.1\%), married (62.5\%) and living in other hospital units (87.5\%) in which he was hospitalized. When analyzing the association between these variables and the outcome, statistically significant differences were observed.
Table 1. Demographic characteristics associated with outcome ( $n=72$ elderly).

\begin{tabular}{|c|c|c|c|c|}
\hline \multirow{2}{*}{ Variables } & \multirow{2}{*}{$\begin{array}{l}\text { Population } \\
\text { total n(\%) }\end{array}$} & \multicolumn{2}{|c|}{ Outcome n(\%) } & \multirow{2}{*}{$P$} \\
\hline & & Discharge & Death & \\
\hline \multicolumn{5}{|c|}{ Age (in years) } \\
\hline $60-69$ & $27(37.5)$ & 19(70.4) & $08(29.6)$ & \multirow{3}{*}{0.153} \\
\hline $70-79$ & 26(36.1) & 16(61.5) & $10(38.5)$ & \\
\hline$\geq 80$ & $19(26.4)$ & $08(42.1)$ & $11(57.9)$ & \\
\hline \multicolumn{5}{|l|}{ Gender } \\
\hline Female & 28(38.9) & $17(60.7)$ & $11(39.3)$ & \multirow{2}{*}{0.545} \\
\hline Male & $44(61.1)$ & $26(59.1)$ & 18(40.9) & \\
\hline \multicolumn{5}{|c|}{ Marital Status } \\
\hline Married & $45(62.5)$ & $28(62.2)$ & $17(37.8)$ & \multirow{3}{*}{0.814} \\
\hline Widower & $21(29.2)$ & $12(57.1)$ & $09(42.9)$ & \\
\hline Silgle & $06(8.3)$ & $03(50.0)$ & $03(50.0)$ & \\
\hline \multicolumn{5}{|c|}{ Marital Status } \\
\hline Other Unit & $63(87.5)$ & $39(61.9)$ & $24(38.1)$ & \multirow{3}{*}{0.345} \\
\hline $\begin{array}{l}\text { Other } \\
\text { hospital }\end{array}$ & $05(6.9)$ & $03(60.0)$ & $02(40.0)$ & \\
\hline Residency & $04(5.6)$ & $01(25.0)$ & $03(75.0)$ & \\
\hline \multicolumn{2}{|c|}{$P=$ Pearson's chi-square. } & \multicolumn{3}{|c|}{ Source: Survey data. } \\
\hline
\end{tabular}

In the association between age and outcome, using Pearson's chi-square, there was no statistically significant difference. However, when applied the Wilcoxon-Mann-Whitney test to analyze the age group interval way, it was observed that the group of elderly people who died had an average age of 76.1 years old $( \pm 9.19)$, higher than group that was discharged, which had an average age of 71.58 ( \pm $23.8)$, with statistical significance $(p=0.04)$. (Data not shown in table)

Table 2 shows the distribution of variables: reason for admission, including whether it was surgery and the type of surgery, the most common chronic diseases. We found a significant correlation between cause of hospitalization and outcome $(p<0.001)$, showing the postoperative as the first cause of hospitalization (47.2\%), and acute respiratory failure (ARF), most responsible (73.9\%) 
for the occurrence of deaths. Like other reasons for hospitalization were identified trauma, pemphigus foliaceus, classic dengue, decompensated diabetes mellitus (DM), cerebrovascular accident (CVA), chronic obstructive pulmonary disease (COPD), sepsis, acute myocardial infarction (AMI), heart block, arrhythmias, gastrointestinal bleeding and liver diseases.

In the post-operative association with outcome, it was observed that among the elderly who have undergone surgical procedure, $88.2 \%$ had discharge for improvement; of those who did not undergo, $65.8 \%$ had as outcome the death $(p<0.001)$. There was a predominance of surgeries involving the abdomen (52.9\%), such as esophagectomy, jejunostomy, gastrectomy, partial hepatectomy; followed by cardiovascular surgeries, represented by endarterectomy (resulting from aneurysm) and cardiomyotomy; and others as a member of amputations caused by complication of diabetic vasculopathy, and prostatectomy (Data not shown in table). In relation to chronic diseases, it was found that DM was the most frequent $(41.7 \%)$, responsible for the higher frequency of death outcomes.

Table 3 shows the association between chronic diseases and hospitalization reason, according to age. It was observed that the DM affects all age groups. However, in the group of 70 to 79 years old it is more frequently (57.7\%); while the DM and Hypertension had the same percentage (31.6\%) in the group aged 80 years or over. There was no statistical dependence on the correlations of age with chronic diseases $(p=0.056)$ and the reason for hospitalization ( $p=0.307)$.
Table 2. Clinical characteristics and comorbidities associated with outcome ( $n=72$ elderly).

\begin{tabular}{|c|c|c|c|c|}
\hline \multirow{2}{*}{ Variables } & \multirow{2}{*}{$\begin{array}{l}\text { Total } \\
\text { n(\%) }\end{array}$} & \multicolumn{2}{|c|}{ Outcome n(\%) } & \multirow{2}{*}{$\boldsymbol{P}$} \\
\hline & & Discharge & Death & \\
\hline \multicolumn{5}{|c|}{ Reason for hospitalization } \\
\hline Post-operatory & $34(47.2)$ & $30(88.2)$ & $04(11.8)$ & \multirow{3}{*}{$<0.001$} \\
\hline ARF & 23(31.9) & $06(26.1)$ & $17(73.9)$ & \\
\hline Other* & $15(20.8)$ & $07(46.7)$ & $08(53.3)$ & \\
\hline \multicolumn{5}{|l|}{ Post-operatory } \\
\hline Yes & $34(47.2)$ & $30(88.2)$ & $04(11.8)$ & \multirow{2}{*}{$<0.001$} \\
\hline No & $38(52.8)$ & $13(34.2)$ & $25(65.8)$ & \\
\hline \multicolumn{5}{|l|}{ Type of surgery } \\
\hline Abdominal & $18(52.9)$ & 16(88.9) & $02(11.1)$ & \multirow{3}{*}{0.973} \\
\hline Cardiovascular & $07(20.6)$ & $06(85.7)$ & $01(14.3)$ & \\
\hline Other** & $09(26.5)$ & 08(88.9) & 01(11.1) & \\
\hline \multicolumn{5}{|c|}{ Chronic Diseases } \\
\hline DM & $30(41.7)$ & $17(56.7)$ & $13(43.3)$ & \multirow{5}{*}{0.101} \\
\hline Hypertension & $17(23.6)$ & $14(82.4)$ & $03(17.6)$ & \\
\hline CVA & $04(5.6)$ & $01(25.0)$ & $03(75.0)$ & \\
\hline COPD & $04(5.6)$ & $01(25.0)$ & $03(75.0)$ & \\
\hline Other*** & $17(23.6)$ & 10(58.8) & $07(41.2)$ & \\
\hline \multicolumn{5}{|c|}{$\begin{array}{l}\text { * Trauma, Pemphigus Foliaceus, classic dengue, Decompensated } \\
\text { DM, sepsis, AMI, atrioventricular block, arrhythmias, } \\
\text { gastrointestinal bleeding and liver diseases. } \\
\text { ** Member amputations and prostatectomy. } \\
\text { *** Neoplasm, Chagas disease, Alzheimer's disease, systemic } \\
\text { lupus erythematosus (SLE), chronic renal failure (CRF), } \\
\text { congestive Heart Failure (CHF), anemia. } \\
p=\text { Pearson's chi-square. }\end{array}$} \\
\hline
\end{tabular}

Table 3. Clinical factors associated to age $(n=72$ elderly).

\begin{tabular}{|c|c|c|c|c|}
\hline \multirow{2}{*}{ Variables } & \multicolumn{3}{|c|}{ Age (in years) n (\%) } & \multirow{2}{*}{$P$} \\
\hline & $60-69$ & 70-79 & $\geq 80$ & \\
\hline \multicolumn{5}{|c|}{ Chronic diseases } \\
\hline DM & 09(33.3) & $15(57.7)$ & 06(31.6) & \multirow{5}{*}{0.056} \\
\hline Hypertension & 05(18.5) & $06(23.1)$ & 06(31.6) & \\
\hline CVA & 01(3.7) & - & $03(15.8)$ & \\
\hline COPD & $01(3.7)$ & $01(3.8)$ & $02(10.5)$ & \\
\hline Other & $11(40.7)$ & $04(15.4)$ & $02(10.5)$ & \\
\hline \multicolumn{5}{|c|}{ Chronic diseases } \\
\hline Post-operatory & $17(63.0)$ & $11(42.3)$ & 06(31.6) & \multirow{3}{*}{0.307} \\
\hline ARF & $06(22.2)$ & $09(34.6)$ & $08(42.1)$ & \\
\hline Other & $04(14.8)$ & $06(23.1)$ & $05(26.3)$ & \\
\hline \multicolumn{3}{|c|}{$P$ - Pearson's chi-square } & Source: Sur & ey data \\
\hline
\end{tabular}




\section{Discussion}

With the increasing aging population and increased longevity, more and more elderly population becomes user of intensive care units, making it necessary to deepen studies that show the clinical characteristics and factors related to the prognosis of the elderly in these units.

The average age of the elderly of this study was of 73.39 years old, considerably high, confirming other findings. $[2,11]$ The growing number of people aged 60 or over, as well as the increase in life expectancy, a rise in admissions of patients in this age group in the ICU. [2] Thus, the elderly client takes, every day, more hospital beds and tends to be a large clientele of general ICU in the future. [12]

This research identified the average general hospital $(8,65$ days] higher than that identified in the 2nd Brazilian ICU Census (between 1-6 days). [13] It is known that prolonged ICU stay may affect the health status of elderly patients due to exposure to infections, invasive measures related to procedures and medications, appearance of pressure ulcers and other complications, resulting in a worse prognosis. In this sense, authors state that prolonged length of stay in ICU "is more common in critically ill patients on admission and is associated with a higher rate of hospital mortality". [14]

The general mortality study of elderly has considerably high, affecting mainly the group with more advanced age, corroborating other authors. $[15,16]$ In Brazil, in adult ICU, the general mortality rate is between $10-56 \%,[17,18]$ while the mortality of the elderly is between $28-62 \%$. [16, 19] In a study to evaluate risk factors for death among critically ill elderly, it was observed that the age of 80 years old, associated with higher mortality and it was highlighted that the delay in the elderly ICU admission is a risk factor for poor prognosis. [16]

In the ICU, depending on the number of beds and the cost, it is necessary to adopt criteria for admission and discharge, prioritizing the hospitalization of patients most likely to recovery and high, excluding those that have a worse prognosis, which often end up being older. [15, 19, 20]

Studies point to age as a factor related to higher mortality, $[16,21]$ but warned that age alone should not be related to worse prognosis. [22, 23] Other associated factors such as severity of acute illness, co-morbidities and functional status appear to be responsible for a worse prognosis. [22-24] Thus, it is observed that several associated factors can be considered a risk factor for death of elderly in ICU, confirming other findings, when emphasize that multiple organ dysfunction can result in high mortality rate. [22]

There was a significant association between outcome and reason for admission, the majority of hospitalizations for clinical diagnosis. However, the postoperative proved to be one cause of hospitalization, especially surgeries involving the abdomen, taking the elderly to a good evolution for improving the ICU. Acute respiratory failure was the second of the elderly reason for hospitalization in the ICU and largely responsible for unfavorable outcomes of older people in these units.

Findings of another study also point out that medical patients account for most of these units, with more severe that surgical. [11] This study showed that, regardless of age or type of surgery, when the reason for ICU admission is surgical, the elderly presents a good clinical outcome. Importantly, the elderly patient who has undergone surgery and is in the ICU needs special care due to surgical stress. Thus, any changes that are identified in the postoperative period are corrected as soon as possible, either by surgical team, as by intensivists. It is notable also that the majority of surgeries were elective order, and probably the elder had a good preoperative preparation, including control of the clinical picture of chronic diseases.

The ARF was the second main reason for ICU admission, accounting for 23 of the hospitaliza- 
tions and the higher incidence of deaths in the study population, confirming other findings. [16, 20] Aging leads to a decrease in capacity and lung efficiency, making the elderly more disposed to changes in respiratory function, especially in the presence of acute diseases which consequently lead to respiratory failure. In this regard, it is stated that the incidence of respiratory failure increases significantly with age, especially in the elderly over 65 years old. [25]

In relation to chronic diseases presented by the elderly, it was found that diabetes and hypertension were the most frequent, the first being more common. These conditions were also identified frequently in previous studies. [16] Chronic disease is the leading cause of disability among the elderly and when they have acute exacerbations, need often in the ICU hospitalization. [5] Among chronic diseases, the DM is high prevalence for the elderly, often diagnosed when installing the sequelae and hypertension is considered "silent killer", [6] the rapidly changing and difficult to treat this age group. In Brazil, "it is estimated that at least $60 \%$ of Brazilian elderly individuals aged 60 or over, are hypertensive". [26]

Among other comorbidities were also identified neoplasms, Chagas' disease, Alzheimer's disease, SLE, CRF, CHF and anemia, chronic diseases considered important, it seems also cause changes in the clinical and hemodynamic instability in the elderly already severely finds sick. Researchers say chronic diseases, type hypertension, diabetes mellitus, stroke, bone disease and cancer, require more intensive concern because endanger the health of the elderly as a whole, making them more fragile. [27]

In terms of age, it was observed that the DM most affects the population group between 70-79 years old and those aged 80 and over are equally affected by both the DM and by hypertension. On the latter, US study says that "blood pressure increases linearly with age". [26]
It is believed that hospitalizations and premature deaths related to diseases, especially diabetes and hypertension, could be avoided if patients and their families have adequate knowledge about the disease, the severity of the treatment, the existence of complications in the short and long term and the appropriate and effective means of prevention. However, what is observed in the ICU is an increased frequency of hospitalization of elderly patients with these diseases.

It is therefore a major challenge to be faced by the health sector, find strategies to raise awareness of proper care in order to prevent acute exacerbations of chronic diseases and therefore hospitalizations of the elderly in ICU. In this regard, studies show the need for changes in the practice of health professionals, particularly with regard to advice and should take into account the knowledge and practices of the individual. [28]

As noted in this study, most of the elderly were hospitalized for acute illnesses, but had a history of chronic diseases. In this regard, researchers report that when acute and chronic diseases interact with each other and with the aging changes, the patient may have many complaints or a chief complaint that cannot be explained by a single disease. [6] In this way, Costa et col state that "a disease may mask worsen and trigger the manifestation of others." [29] So it seems that the association between acute and chronic diseases linked to physiological limitations resulting from the aging process may interfere with the elderly care in the ICU, and result in a worse outcome, considering the claim that physiological changes of aging, multi-morbidities, medications, atypical presentations and needs for more complex diagnostic interventions to clarify the framework, delays diagnosis and cause greater severity of the frames. [6]

Thus, in the old ICU admission, analysis of prior information, as well as "be important in determining whether we are facing an atypical presentation, also allows to determine the urgency or not 
the clinical picture" is critical. [6] This unit are made need to be identified and addressed chronic diseases for better clinical management of the reason that led the elderly to this sector. [8]

\section{Conclusion}

In this study it was observed that clinical patients represented most of the elderly. But the main reason for admission of these in the ICU is a surgical procedure that in a good clinical evolution and discharge, due to improvement in this unit.

It is remarkable that knowledge about the clinical features and prognostic factors of elderly ICU can contribute to action planning assistance and early intervention, improving performance in assisting the elderly with a view to reducing the incidence of mortality, health promotion, functional status and quality of life of the elderly.

\section{References}

1. Instituto Brasileiro de Geografia e Estatística [Internet]. Brasília: Ministério do Planejamento, Orçamento e gestão (BR). Características gerais da população, religião e pessoas com deficiência. Censo 2010. Available from: http://www.ibge. gov.br/home/presidencia/noticias/noticia visualiza.php?id noticia $=217$

2. Feijó CAR, Bezerra ISAM, Peixoto Junior AA, Meneses SA. Morbimortalidade do idoso internado na Unidade de Terapia Intensiva do Hospital Universitário de Fortaleza. Rev. bras. de ter. intensiva [Internet]. 2006; 18 (3): 263-7. Available from: http:// www.scielo.br/pdf/rbti/v18n3/v18n3a08.pdf. DOI: 10.1590/ S0103-507X2006000300008

3. Feijó CAR, Leite Júnior FO, Martins ACS, Furtado Júnior AH, Cruz LLS, Menezes FA. Gravidade dos pacientes admitidos à unidade de terapia intensiva de um hospital universitário Brasileiro. Rev Bras Ter Intensiva [Internet]. 2006;8 (1): 18-21. Available from: http://www.scielo.br/pdf/rbti/v18n1/a04v18n1. DOI: 10.1590/ S0103-507X2006000100004

4. Nasri F, Toniolo Neto J, Nussbacher A. Abordagem do paciente idoso grave. In: Knobel E. Condutas no paciente grave. 3a ed. São Paulo: Atheneu; 2007. p. 2055-70.

5. Morton PG, Fontaine DK, Hudak CM, Gallo BM. Cuidados críticos de enfermagem: uma abordagem holística. 8a ed. Rio de Janeiro: Koogan; 2007. 1389 p.
6. Gorzoni ML, Elisa FAC, Meneses MCL. Comorbidade, multimorbidade e apresentações atípicas das doenças nos idosos. In: Freitas EV, Py L, Cançado FAX, Doll J, Gorzoni ML. Tratado de geriatria e gerontologia. 3a ed. Rio de Janeiro: Koogan; 2011; p. 931- 44.

7. Fonseca ACF, Fonseca MJMF. Cuidados paliativos para idosos na unidade de terapia intensiva: realidade factível. Scientia Medica [Internet]. 2010; 20 (4): 301-309. Available from: http:// revistaseletronicas.pucrs.br/ojs/index.php/scientiamedica/ article/viewFile/7510/5829 LILACS: 583409

8. Sitta MC, Jacob Filho W, Farfel JM. O Idoso no Centro de Terapia Intensiva. In: Freitas EV, Py L, Cançado FAX, Doll J, Gorzoni ML. Tratado de geriatria e gerontologia. 3a ed. Rio de Janeiro: Koogan. 2011; p.1243-6.

9. Marik PE. Management of the critically ill geriatric patient. Crit Care Med [internet]. 2006; 34 (9): 176-82. Available from: http:// www.ncbi.nlm.nih.gov/pubmed/16917421. PMID: 16917421

10. Brasil, Ministério da Saúde, Conselho Nacional de Saúde. Diretrizes e Normas Regulamentadoras de Pesquisa Envolvendo Seres Humanos: Resolução 466/12. Brasília; 2012. Available from: http://www.conselho.saude.gov.br/resolucoes/2012/Reso466.pdf.

11. Acuña K, Costa E, Grover A, Camelo A, Santos Júnior R. Características clínico-Epidemiológicas de adultos e idosos atendidos em unidade de terapia intensiva pública da Amazônia (Rio Branco, Acre). Rev. Bras. Ter. Intensiva [Internet]. 2007; 19 (3): 304-9. Available from: http://www.scielo.br/pdf/rbti/v19n3/ v19n3a06.pdf. DOI: 10.1590/S0103-507X2007000300006

12. Guedes EP, Marra CC. Prevenção de iatrogenias em idosos em unidades de terapia intensiva. Rev. Enferm. UNISA [internet]. 2002; 3: 57-2. Available from: http://www.unisa.br/graduacao/ biologicas/enfer/revista/arquivos/2002-11.pdf

13. Orlando JMC, Milani CJ. $2^{\circ}$ Anuário Brasileiro de UTIs $-2^{\circ}$ Censo Brasileiro de UTIs. São Paulo: Associação de Medicina Intensiva Brasileira (AMIB); Edição 2002-2003.

14. Abelha FJ, Castro MA, Landeiro NM, Neves AM, Santos CC. Mortalidade e o tempo de Internação em uma unidade de terapia intensiva cirúrgica. Rev Bras Anestesiol [internet]. 2006; 56 (1): 34-5. Available from: http://www.scielo.br/pdf/rba/v56n1/ v56n1a05.pdf. DOI: 10.1590/S0034-70942006000100005

15. Ciampone JT, Gonçalves LA, Maia FOM, Padi KG. Necessidades de cuidados de enfermagem e intervenções terapêuticas em unidade de terapia intensiva: estudo comparativo entre pacientes idosos e não idosos. Acta Paul Enferm [internet]. 2006; 19 (1): 28-35. Available from: http://www.scielo.br/pdf/ape/v19n1/ a05v19n1.pdf. DOI: 10.1590/S0103-21002006000100005

16. Alves GC, Silva Júnior GB, Lima RSA, Sobral JB, Mota RMS, Abreu KLS, et al. Fatores de risco para óbito em pacientes idosos gravemente enfermos. Rev. Bras. Ter. Intensiva [Internet]. 2010; 22 (2): 138-43. Availablefrom: http://www. scielo.br/pdf/rbti/v22n2/a07v22n2.pdf. DOI: $10.1590 /$ S0103507X2010000200007

17. Silva Junior JM, Malbouisson LMS, Nuevo HL, Barbosa LGT, Marubayashi LY, Teixeira IC, et al. Aplicabilidade do Escore Fisiológico Agudo simplificado (SAPS 3) em Hospitais Brasileiros. Rev Bras de Anestesiologia [Internet] 2010; 60 (1): 20-31. Available from: http://www.scielo.br/pdf/rba/v60n1/v60n1a03. pdf. DOI: 10.1590/S0034-70942010000100003 
18. Freitas ERFS. Perfil e gravidade dos pacientes das unidades de terapia intensiva: aplicação prospectiva do escore APACHE II. Rev. Latino-Am. Enfermagem [internet]. 2010; 18 (3): 20-6. Available from: http://www.scielo.br/pdf/rlae/v18n3/pt 04.pdf. DOI: 10.1590/S0104-11692010000300004

19. Alves CJ, Franco GPP, Nakata CT, Costa GLG, Genaro MS'A, Agostini $G$, et al. Avaliação de índices prognósticos para pacientes idosos admitidos em unidade de terapia intensiva. Rev. bras. de ter. intensiva [Internet]. 2009; 21 (1): 1-8. Available from: http://www.scielo.br/pdf/rbti/v21n1/v21n1a01.pdf. DOl: 10.1590/S0103-507X2009000100001

20. Schein LEC, Cesar JA. Profile of elderly people hospitalized in general intensive care units in Rio Grande, Southern Brazil: Results of a cross-sectional survey. Rev Bras Epidemiol [internet]. 2010; 13 (2): 1-10. Available from: http://www.scielo.br/ pdf/rbepid/v13n2/en 11.pdf. Schein. DOI: 10.1590/S1415790X2010000200011

21. Bezerra GKA. Modelo de regressão logística para previsão do óbito na unidade de terapia intensiva. João Pessoa/PB. Dissertação [Pós graduação em modelos de decisão em saúde] - Universidade Federal da Paraíba; 2012.

22. Minne L, Ludikhuize J, Jonge E, Rooij S, Abu-Hanna A. Prognostic models for predicting mortality in elderly ICU patients: a systematic review. Intensive Care Med [Internet]. 2011; 37: 1258-68. Available from: http://link.springer.com/ article/10.1007\%2Fs00134-011-2265-6\#page-1. DOI: 10.1007/ s00134-011-2265-6

23. Rooij SE, Abu-Hanna A, Levi M, Jonge E. Factors that predict outcome of intensive care treatment in very elderly patients: a review. Critical Care [Internet] 2005; 9 (4): 307-14. Available from: http://www.ncbi.nlm.nih.gov/pmc/articles/PMC1269437/ pdf/cc3536.pdf. DOI: 10.1186/cc3536

24. Rooij SE, Abu-Hanna A, Levi M, Jonge E. Identification of highrisk subgroups in very elderly intensive care unit patients. Critical Care [internet] 2007; 11 (2): 2-9. Available from: http://ccforum. com/content/11/2/R33. DOI: 10.1186/cc5716

25. Behrendt CE. Acute respiratory failure in the United States: incidence and 31-day survival. Chest [internet]. 2000; 118 (4): 1100-5. Available from: http://journal.publications.chestnet.org/ article. aspx?articleid=1079214. PMID: 11035684
26. Mion Jr. D, Kohlmann Jr. O, Machado CA, Amodeo C. Gomes MAM, Praxedes JN et al (orgs.). V Diretrizes Brasileiras de Hipertensão Arterial. Arq Bras Cardiol [internet] 2007; 89 (3): e24-e79. Available from: http://www.scielo.br/pdf/abc/v89n3/ a12v89n3.pdf. DOI: 10.1590/S0066-782X2007001500012

27. Zaslavsky C, Gus I. Idoso: doença cardíaca e comorbidades. Arq Bras Cardiol [internet]. 2002; 79 (3): 635-9. Available from: http://www.scielo.br/pdf/abc/v79n6/13766.pdf. DOI: 10.1590/ s0066-782X2002001500011

28. Cavalari E, Nogueira MS, Hayashida M, Cesarino CB, Alves LMM, Fava SMCL. Fatores relacionados aos níveis pressóricos de indivíduos hipertensos em seguimento ambulatorial. Rev. Eletr. Enf. [Internet] 2012; 14 (3): 603-9. Available from: http://www.fen.ufg.br/revista/v14/n3/v14n3a17.htm. DOI: 10.5216/ree.v14i3.15616

29. Costa EFA, Porto CC, Almeida JC, Cipullo JP, Martin JFV. Semiologia do idoso. In: Porto CC. Semiologia médica. 6a ed. Rio de Janeiro: Koogan; 2009. p.159-193.

\section{Comment on this article:}

\section{$4[8$ in $8+\mathbf{S} P$}

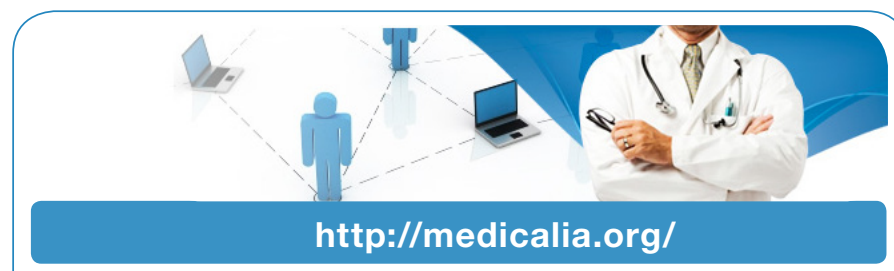

Where Doctors exchange clinical experiences, review their cases and share clinical knowledge. You can also access lots of medical publications for free. Join Now!

\section{Publish with iMedPub}

http://www.imed.pub

International Archives of Medicine is an open access journal publishing articles encompassing all aspects of medical science and clinical practice. IAM is considered a megajournal with independent sections on all areas of medicine. IAM is a really international journal with authors and board members from all around the world. The journal is widely indexed and classified Q1 in category Medicine. 